\title{
Skydning, gymnastik og sport på Skiveegnen 1870-1914
}

Af Niels Mortensen

Skydning og gymnastik på landet og engelsk sport i byen - sådan lyder den klassiske fremstilling af Danmarks tidlige idrætshistorie i ultrakort form. Undersøger man spørgsmålet på lokalt plan, når man i dag frem til en helt anden historie.

Sådan forholder det sig i det mindste for Skiveegnen (købstaden Skive og dens omegn: Salling og Fjends i Viborg Amt samt den nordøstligste del af Ginding Herred (Vinderupegnen) i Ringkøbing Amt), som udgør området for denne artikel.

Købstaden Skive ligger i centrum af området. Skive havde i 18802.521 indbyggere. I 1911 var indbyggertallet vokset til 6.782 inkl. forstæder. Skives vækst var først og fremmest båret af en stærk stigning i velstanden hos landboerne i omegnen - byens vigtigste marked. Omegnens efterspørgsel skabte basis for en vis industriel udvikling og en stor vækst $i$ antallet af butikker og håndværksvirksomheder fra omkring 1890. På samme tid opstod der større og mindre stationsbyer langs egnens jernbaner.

På Skiveegnen blev skydning og gymnastik for alvor populære idrætsgrene fra 1880 'erne, men de fik konkurrence fra cykelsporten i 1890'erne og fra fodbold efter 1900. Allerede få år inde i det nye århundrede var fodbold lige så populær som skydning og gymnastik. Og de enkelte idrætsgrene slog igennem omtrent samtidig $\mathrm{i}$ byen og på landet.

\section{Skyttebevagelsen på Skiveegnen}

De første, nogenlunde levedygtige skytteforeninger på Skiveegnen oprettedes i perioden 1867-1870. I 1870 - året efter oprettelsen af Viborg Amts Skytteforening fandtes der - ud over skytteforeningen i Skive - fem skytteforeninger i Salling og en i Fjends, men flere af dem forsvandt $i$ løbet af kort tid. Ti år senere fandtes der kun to skytteforeninger i Salling og fire i Fjends.

De levedygtige skytteforeninger havde alle tilknytning til de grundtvigianske miljøer på egnen.

Vejby-kredsen i Vestsalling lå i et område, der var præget af folkelige vækkelser i begyndelsen af det 19. århundrede og senere af markante grundtvigske præster.

Jebjerg-Lyby Skyttekreds i Midtsalling havde som formand $\mathrm{i}$ en lang årrække grundtvigianismens førstemand i Salling, pastor Niels Krestjan Glud. Glud havde en lang række tillidsposter inden for skyttebevægelsen fra slutningen af 1860'erne og omtrent indtil sin død i 1925. Han løsnede aldrig selv et skud eller deltog i gymnastikken. Interessen for skyttebevægelsen skyldtes nationale, politiske, moralske og pædagogiske overvejelser. Glud ville først og fremmest opdrage og oplyse de unge.

I Nordfjends, hvor der i 1880 fandtes skytteforeninger i Højslev, Ørslevkloster, 
Ørum og Tårup-Kvols-Borris, fandtes der et grundtvigiansk miljø omkring pastor Vilhelm Malling i Ørslevkloster-Ørum.

I disse tre områder, hvor grundtvigianerne og skytteforeningerne stod stærkt, opførtes Skiveegnens første forsamlingshuse: Vestsalling (Ramsing 1879), Midtsalling (Jebjerg 1881) og Nordfjends (Ørum 1883). Disse forsamlingshuse var tænkt som samlingssted for en hel egn, og de blev financieret ved aktietegning blandt »vennerne«, herunder skytteforeningerne. Aktionærerne i Ørum Forsamlingshus kom f.eks. fra hele Nord- og Midtfjends. Forsamlingshusene i Ramsing og Ørum var ottekantede bygninger, og modellen fandt man i det store forsamlingshus i Galtrup på Mors (opført 1876).

\section{Gymnastikken}

Skydningen var en udendørs sommersport, som sluttede med skytteforeningens præmieskydning og skyttebal om efteråret. Ved siden af skydningen gjorde nogle skyttekredse gymnastik »på skolens grønning « (Jebjerg-Lyby) eller øvede eksercits (Højslev), men skydning var hovedaktiviteten. Det ændrede forsamlingshusene på. Fra begyndelsen af 1880 'erne blev gymnastikken i forsamlingshuset om vinteren en aktivitet på linje med sommerskydningen, sluttende om foråret med gymnastikpræsentationen og gymnastikballet.

Efter indførelsen af gymnastikken fik skytteforeningerne lettere ved at overleve. Nu kunne de arbejde hele året i stedet for at ligge døde hele vinteren, samtidig med at de fik flere strenge at spille på. Efterhånden blev det mere og mere almindeligt, at nogle medlemmer kun dyrkede gymnastik og ikke ønskede at deltage i skydeøvelserne.

Gymnastikkens indtog kan følges i Højslev Skyttekreds (stiftet 1880). I 1882 begyndte skyttekredsen at tilbyde gymnastik om vinteren. Gårdejer N.P. Bæk, der sammen med møller N. Jeppesen var initiativtager til kredsens oprettelse, underviste i begyndelsen i gymnastik i sin dagligstue. I 1883 fik Bæk kursus i dansk gymnastik på Askov Højskole. Efter hjemkomsten ombyggede han et af sine udhuse til gymnastiksal.

I 1884 fik den 18-årige ungkarl Chr. Larsen, Halskov, et tilsvarende kursus på Askov. Året efter var han af sted igen, men nu for at lære den »lingske« eller »svenske« gymnastik hos højskolelærer Poul la Cour. Ved Viborg Amts Skytteforenings gymnastikfest i sommeren 1886 præsenterede han den nye gymnastik for første gang. Som måske den første skyttekreds på egnen tilbød kredsen gymnastik for piger og drenge. I 1888 viste børnene deres kunnen ved amtsgymnastikfesten. Fra 1894 fik kredsen bedre muligheder for at $\varnothing v e$ gymnastik. Møller Jeppesen opførte en forsamlingsbygning, »Vennely«, som han stillede til rådighed for skyttekredsen, afholdsforeningen m.fl. Her dyrkede Højslev Skyttekreds gymnastik og holdt skytte- og gymnastikballer - uden alkohol! - indtil 1902, hvor Jeppesen overtog »Vennely « som privatbolig. Dette år byggedes så et almindeligt forsamlingshus i Højslev, som brugtes til gymnastik af skyttekredsens karle-, drenge- og kvindehold, som nu også var kommet til.

\section{Skytter og gymnaster}

Før forsamlingshusene skød op over hele landet i 1890 'erne, var skydningen den altdominerende idræt inden for skyttebevægelsen, selvom flere kredse også dyrkede gymnastik. Fra midten af 1890'erne begyndte gymnastikken at fylde stadig mere. Dens gennembrud kom efter århundredskiftet, 


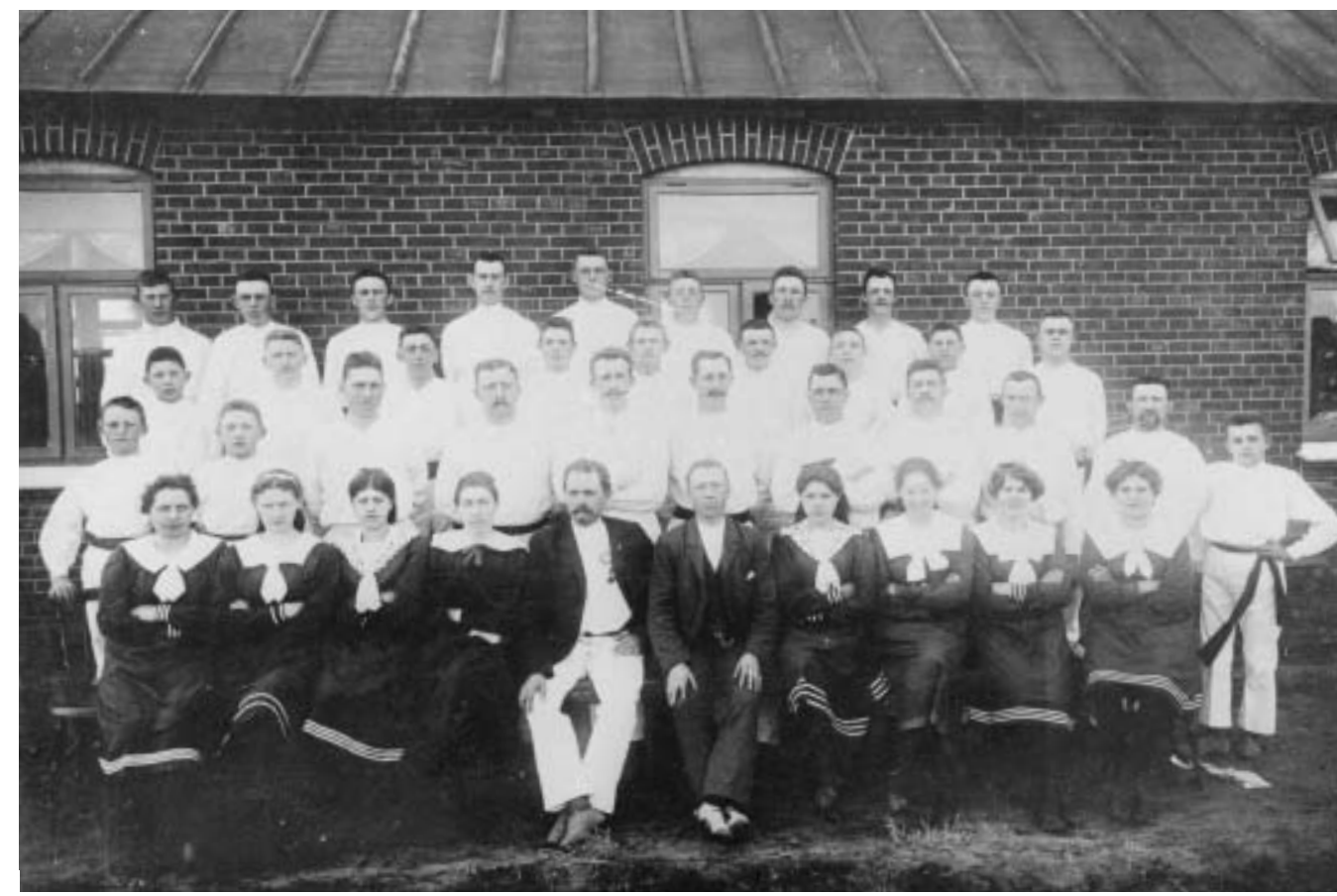

Højslev Skyttekreds' pige- og karlehold, fotograferet ved kredsens gymnastikfest foråret 1904. Højslev Skyttekreds (stiftet 1880) var en af Skiveegnens celdste og mest solide skytteforeninger. Det skyldtes ikke mindst Chr. Larsen ( $\mathrm{nr}$. fem fra venstre i forreste rakke), der som 19-årig $i 1885$ var på kursus i svensk gymnastik hos Poul la Cour $i$ Askov. En uge efter skyttekredsens gymnastikprasentation blev Højslev Boldt-Forening stiftet. Flere af skyttekredsens medlemmer kom i fodboldforeningens ledelse, bl.a. laerer Veggerby, Højslev, (nr. fem fra venstre i anden rakke), der blev formand.

som det fremgår af nedenstående tabeller, der viser medlemsudviklingen i Viborg Amts Skytteforening og Salling/Salling Herreders Skytteforening fra 1870-1915.

Ved århundredskiftet var der en skyttekreds i hvert sogn, og i adskillige sogne var der flere. I Højslev Sogn (Fjends Herred) var der f.eks. i 1905 fire skyttekredse og en gymnastikforening, der alle stod som medlemmer af Viborg Amts Skytteforening. Langt fra alle foreninger var lige stabile, og de fleste gik i opløsning efter få år. I Højslev var der kun en skyttekreds tilbage ti år senere.
Det er værd at lægge mærke til, at gymnasterne i Viborg Amts Skytteforening er i klart undertal i forhold til skytterne indtil 1915, mens antallet af gymnaster i Salling svarer til antallet af skytter allerede i 1906 og derefter - med undtagelse af et enkelt år (1909) - ligger langt over antallet af skytter. En del af forklaringen på forskellen er formentlig, at Salling i 1884 fik sin egen højskole, Salling Højskole i Jebjerg. Højskolen underviste i gymnastik fra begyndelsen, og i 1887 afholdt højskolen sit første kursus i svensk gymnastik for lærere og delingsførere i skytteforeningerne. 
Tabel 1. Viborg Amts Skytteforenings medlemstal 1870-1915.

\begin{tabular}{rrrc}
\hline & Kredse & Skytter & Gymnaster \\
\hline 1870 & 10 & 266 & \\
1880 & 10 & 250 & \\
1890 & 40 & 1024 & 470 \\
1895 & 56 & 1357 & 354 \\
1900 & 72 & 1560 & 458 \\
1904 & 106 & 1904 & 736 \\
1905 & 76 & 1261 & 567 \\
1910 & 59 & 907 & 248 \\
1915 & 39 & 386 & 429 \\
\hline
\end{tabular}

Viborg Amts Skytteforening dakkede det gamle Viborg Amt (for 1970) (undtagen sognene ved Silkeborg) samt den nordфstligste del af Ringkøbing Amt (Ginding Herred).

Kredsene i Salling og Ginding Herred blev udskilt og omdannet til en selvstandig amtsforening, Salling Herreders Skytteforening, pr. 1. januar 1905.

Samme år indførtes den svenske gymnastik på karleholdet. Sommeren 1888 indviedes фvelseshuset »Videslet «, som få dage senere blev ramme om Viborg Amts Skytteforenings amtsgymnastikfest. Her gav højskolens pigehold og et hold piger fra Højslev Skyttekreds opvisning i svensk gymnastik. Opvisningerne gjorde stort indtryk:

»Da kvinderne under sang marcherede ind på festpladsen, betragtedes de med forventningsfulde, for nogles vedkommende med halvt vantro miner. Øvelsen udfortes let og taktfast... og der var en spaendt, nasten åndel $\phi$ s tavshed over forsamlingen [...] Det turde vare фnskeligt, at flere af Danmarks kvinder snart ville folge disse banebryderes fodspor, så den tanke kan vinde indpas i folks bevidsthed, at mand og kvinde er skabt af samme stof og står lige med hensyn til
Tabel 2. Medlemstal for skytte- og gymnastikforeningerne i Salling m.v. 1894-1915.

\begin{tabular}{cccc}
\hline & Kredse & Skytter & Gymnaster \\
\hline 1894 & 7 & 236 & 64 \\
1895 & 7 & 191 & 74 \\
1898 & 14 & 449 & \\
1903 & 24 & 575 & \\
1904 & 25 & 476 & 131 \\
1906 & 28 & 351 & 348 \\
1907 & 30 & 247 & 406 \\
1909 & 28 & 339 & 328 \\
1910 & 31 & 390 & 584 \\
1912 & 31 & 335 & 539 \\
1914 & 21 & & 412 \\
1915 & & 274 & 393 \\
\hline
\end{tabular}

Fra 1898 omfatter tallene også skytteforeninger $i$ den nordфstligste del af Ringkфbing Amt (Ginding Herred), der stod som medlem af Viborg Amts Skytteforening (indtil 1905) og derefter af Salling Herreders Skytteforening.

menneskerettigheder og menneskepligter $\ll .1$

Det fromme ønske kom til at gå i opfyldelse, selv om det tog lidt tid. Fra 1897 kunne der oprettes foreninger, der kun dyrkede gymnastik, inden for skyttebevægelsen, og herefter begyndte kvinderne for alvor at komme med. I 1910 var der seks af de 31 medlemsforeninger i Salling Herreders Skytteforening, der kun dyrkede gymnastik. I alt 17 kredse (af 31) dyrkede gymnastik, og deltagerne fordelte sig således: 293 mænd, 200 kvinder og 91 drenge. Dette forhold - mænd to tredjedele, kvinder en tredjedel - holdt sig indtil 1915.

Gymnastikkens stigende betydning kom til udtryk ved oprettelsen af Salling Herreders Skytteforening i 1905. Den nye »amtsforening « blev delt i to afdelinger, en skytteafdeling og en gymnastikafdeling med egen pengekasse og ledet af et udvalg 
på tre. De to udvalg udgjorde sammen med en fællesvalgt formand foreningens bestyrelse. Som konsekvens $\varnothing$ nskede foreningens bestyrelse i 1905, at foreningen skulle hedde Salling Herreders Skytte- og Gymnastikforening, ligesom man $\varnothing$ nskede at ændre den hidtidige formålsparagraf, »som man fandt var snaver og havde et noget for militaristisk prag «, til følgende formål:

»dels blandt maend af alle samfundsklasser at udbrede og vedligeholde fardighed $i$ riffelskydning, dels blandt maend og kvinder af alle samfundsklasser gennem gymnastik og legems $\phi v e l s e r$ at udvikle ånden og styrke legemet og derved på en ligeså adspredende som gavnlig måde at udfylde en del af ungdommens fritid.$^{2}$

Disse forslag blev pure afvist af De danske Skytteforeningers overbestyrelse, men de viser, at der var nye tanker på vej inden for skyttebevægelsen.

\section{Skyttebevagelsen og sporten}

Mens de fleste ledere i skytteforeningerne lagde stor vægt på bevægelsens nationale, politiske og opdragende opgaver, var der mange af skytteforeningernes menige medlemmer, der var mere optaget af at blive den bedste skytte eller gymnast og vinde præmier ved kapskydninger og gymnastikfester. Især grundtvigianerne fors $\emptyset$ gte at bekæmpe sportsliggørelsen af skydningen og gymnastikken. Det vigtigste var at være med, ikke at vinde. Derfor ville man af med præmiejageriet, bl.a. ved betalingsskydningen ved skyttefesterne, og man ville have antallet af skyttefester begrænset.

Ved betalingsskydningen, som fandtes ved alle skyttefester, kunne de deltagere, der ville betale for at skyde, vinde penge-

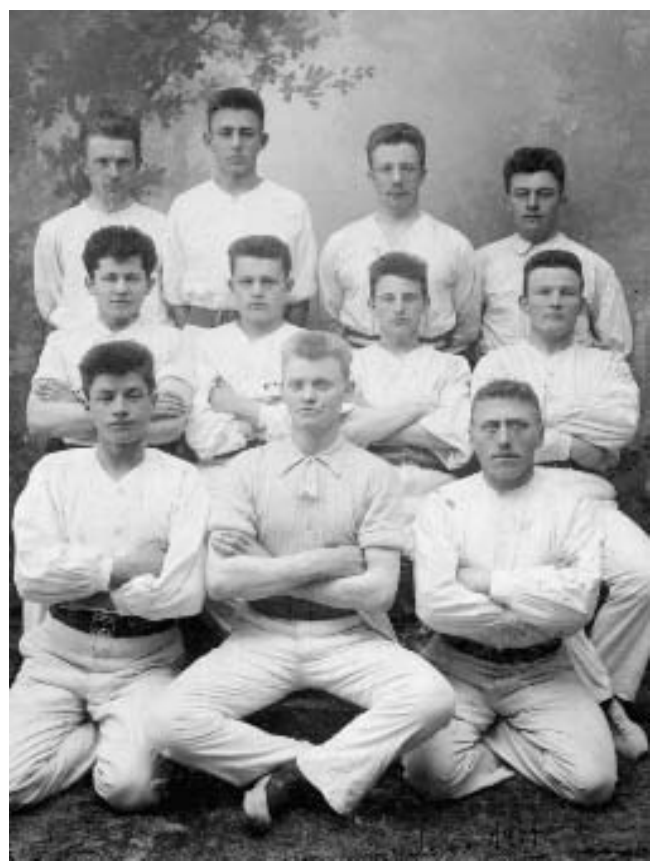

Salling Hojskole i Jebjerg, der blev oprettet $i 1884$ på initiativ af sogneprast og skytteforeningsformand Niels Krestjan Glud, kom til at spille en vaesentlig rolle for udbredelsen af svensk gymnastik på Skiveegnen, bl.a. gennem kurser for egnens larere og for delingsforere i skytteforeningerne. Gymnastikken spillede også en vigtig rolle i den daglige undervisning af karle og piger. Her ses et hold karle, der blev undervist af højskolelaerer Erik Haugaard (bageste rakke til venstre). Foto ca. 1905.

præmier. Man kunne endog skyde ved stedfortræder og vinde præmie uden selv at løsne et skud. Betalingsskydningen var populær, for her kunne dygtige skytter vinde pæne kontante præmier. Det vakte derfor også ved Viborg Amts Skytteforenings skyttefest i 1896 »en del misnøje blandt skytterne, at [promierne] i denne skydning mod sadvane blev uddelt i genstande og ikke i kontanter . $^{3}$ 


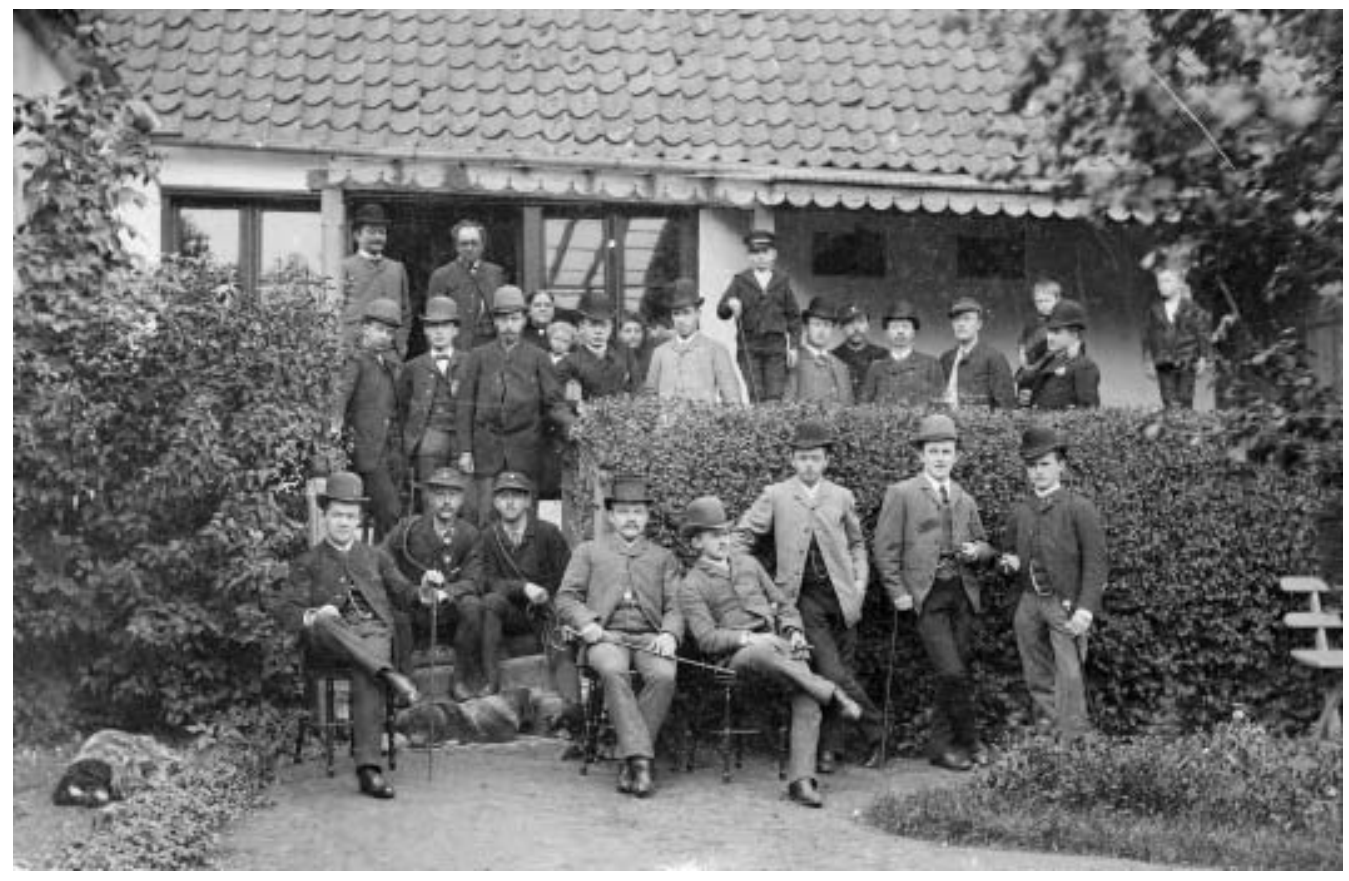

Skives unge gentlemen lufter bowlerhattene i Handels- og Kontoristforeningens have ca. 1900. De unge kommiser og kontorister i foreningen spillede en stor rolle ved oprettelsen af Skives første sportsklubber.

Som led i kampen mod præmiejageriet forsøgte grundtvigianerne at få indskrænket antallet af skyttefester for i stedet at lægge vægten på det daglige arbejde i skyttekredsen.

»Det har jo ikke i mindste måde noget med skyttesagen at gøre således sфndag efter søndag at fare hid og did til disse tossede kapskydninger. Når undtages de enkelte "professionelle skytter", der erhverver sig en hojest tvivlsom fortjeneste og en ligeså tvivlsom are, er disse kapskydninger forbundne med en slet ikke ubetydelig udgift«

til transport, fortæring m.m., som den enkelte skytte selv måtte betale, mente en læserbrevsskribent. ${ }^{4}$ »Derved får man en del sportsskytter til skade for foreningen, da ingen unge under slige omstandigheder melder sig under fanerne «, påpegede formanden for Viborg Amts Skytteforening, pastor Bruun, Levring, på generalforsamlingen i 1901. Fra 1905 måtte skyttekredsene kun deltage i to skyttefester om året, nemlig kredsens lokale fest og amtsskyttefesten.

Også inden for gymnastikken var det galt med præmierne. Ved opvisninger i dansk gymnastik, der lagde hovedvægten på individuelle springøvelser, var det almindeligt at uddele præmier til de bedste gymnaster.

»Gymnastikken kalder på alle, men får for det meste kun tag $i$ dem, som ved med sig selv let at kunne komme efter 
det og altså henter pramie. De mere klodsede og dem med mindre herred $\phi m$ me over legemet holdes tilbage. »De fär ingenting for det«, ingen pramie, og måske kan de blive lét lidt ad i forstningen - nej, så hellere blive derfra - det samme afholder tit de helt unge karle fra at gå med «,

skrev en indsender i Skive Folkeblad. ${ }^{5}$ Det lykkedes kritikerne at få afskaffet enkeltmandspræmierne, så kun de bedste hold fik tildelt præmie ved gymnastikfesterne.

Ud over sportsliggørelsen af skydningen og gymnastikken havde mange ledere også kig på udskænkningen af $\varnothing$ l og spiritus og de offentlige skytteballer. Gang på gang søgte den stærke alliance af grundtvigianere og afholdsfolk at få alkoholen og dansen væk fra skytte- og gymnastikfesterne, men selv ikke i 1911, hvor afholdsbevægelsen i Salling stod allerstærkest, kunne et forslag om at forbyde spiritus og offentlig dans ved Salling Herreders Skytteforenings fester samle mere end en trediedel af stemmerne. Overskuddet fra skytteballerne udgjorde en væsentlig del af indtægterne ved skyttefesterne, som generelt spillede en vigtig rolle $\mathrm{i}$ financieringen af skytteforeningernes daglige drift - og så var ballerne en mulighed for at møde ligesindede og ikke mindst egnens piger, som mange mandlige medlemmer satte stor pris på. Nogle så meget, at de bekymrede skytteledere i Salling også slog ned på »balmedlemmerne« - medlemmer, der »indtegnede sig i skytternes rakke kun for at kunne deltage $i$ kredsenes festligheder «. Løsningen blev, at man fremover kun kunne være medlem af en enkelt skyttekreds og dermed kun deltage i det begrænsede antal fester, som kredsen måtte deltage $\mathrm{i}$.

Skyttebevægelsens ledere var tvunget til at gå på listefødder, for fra 1890 var skytte- kredsene ikke længere alene om at tilbyde idræt til de unge. Sportsforeningerne først cykelklubberne og derefter fodboldforeningerne - var reelle alternativer til skyttekredsene, og her var der ikke problemer med at tilbyde konkurrence og spænding - og så var der altid bal bagefter!

\section{Den engelske sport kommer til Skiveegnen}

Egnens første sportsforening, Skive Skøjteløberforening, blev oprettet i 1885. Initiativtagerne til foreningen var unge kommiser og handelsfolk, formentlig med tilknytning til Handels- og Kontoristforeningen. I denne forening mødtes unge kommiser og kontorister i deres sparsomme fritid til selskabeligt samvær, kortspil og baller. Idealet for foreningens medlemmer var den unge gentleman med bowlerhat, fremgår det af et foto af foreningens medlemmer fra ca. 1900 (se forrige side).

De unge kommiser og kontorister spillede en stor rolle ved oprettelsen af de første sportsforeninger i Skive. Ud over skøjteløberforeningen drejer det sig om Skive Cykleklub (1889), Skive Boldklub (1896) og Skive Roklub (1901).

En anden gruppe af unge, der spillede en vis rolle ved oprettelsen af de første sportsforeninger i Skive, var håndværkerlærlingene og de unge svende. Kommiserne og kontoristerne stod $\mathrm{i}$ et vist modsætningsforhold til hinanden. Det kom f.eks. til udtryk i et læserbrev i forbindelse med oprettelsen af Skive Boldklub i 1896. Forfatteren spørger, hvorfor Skive her midt i 1890'erne kun har en enkelt idrætsforening, Skive Skyttekreds, og svarer selv:

»... det er den latterlige, hovmodige, indbildske, vigtige og storsnudede »fф- 


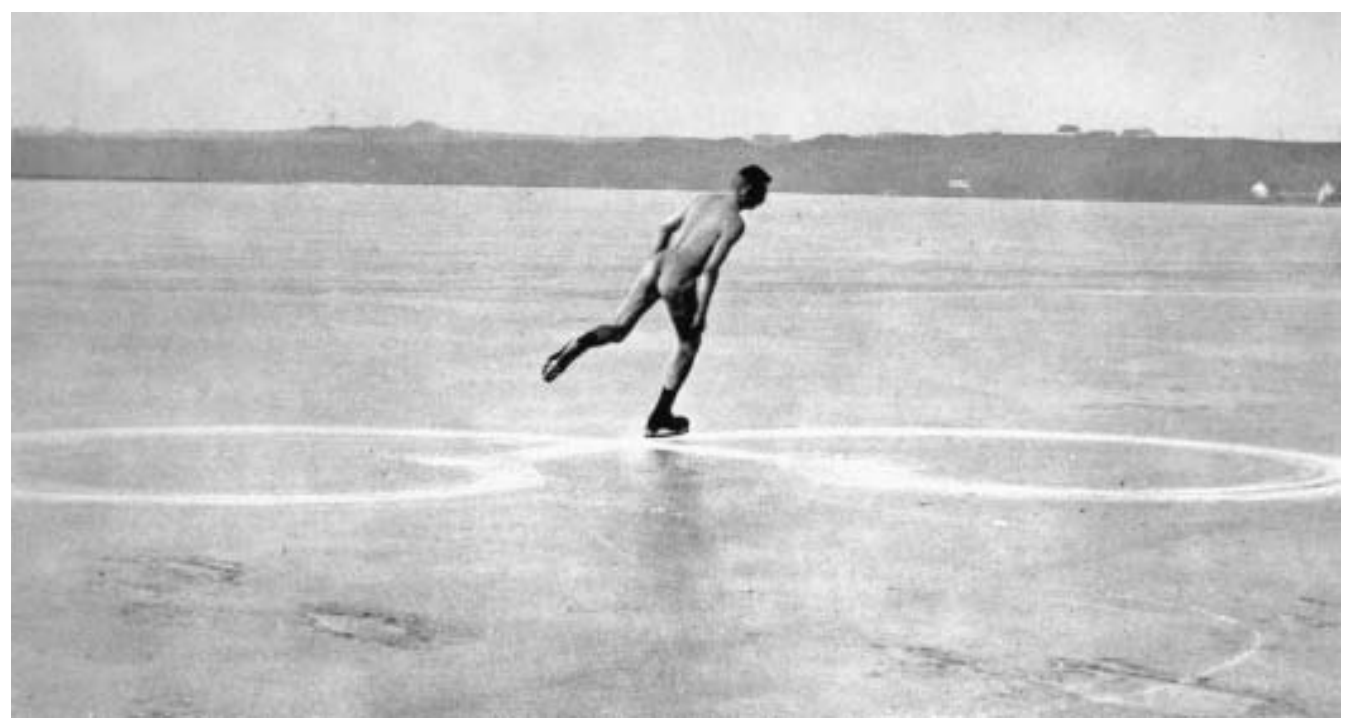

Bankassistent Carl Vilhelm Mфller Hansen lфber på skфjter på den tilfrosne Skive/Karup $\AA$ den 18. januar 1914. 11 dage senere kunne det signerede foto studeres på forsiden af Politiken.

len sig«, der er så fremherskende her [...] Kunne man f.eks. her i Skive tanke sig, at kommiserne og håndvarkssvendene kunne gå i spand sammen. Nappe! Kommiserne ser ned på svendene som laverestående skabninger, og svendene betragter kommiserne som nogle opblceste vigtigmagere. Men når forholdet er det, at standsforskel og hovmod er så udpraget her, bliver det så vanskeligt at holde nogen slags idrcetsforening i Skive, thi på фvelsesmarken må alle vare lige ${ }^{6}{ }^{6}$

Forholdet mellem handels- og kontorfolkene og lærlingene er her sat på spidsen, men læserbrevsskribenten har fat $i$ en pointe. Der kom faktisk til at gå nogle år, før de to grupper kunne samles i den samme idrætsklub.

Håndværkerne - og her først og fremmest håndværkerlærlingene - begyndte først for alvor at markere sig på idrætsområdet i 1898, hvor utilfredse lærlinge oprettede Skive Gymnastikforening. Gymnastikforeningen fusionerede ganske vist i 1901 med Skive Boldklub (Skive Gymnastik- og Boldklub, navneskift i 1906 til Skive Idrætsklub), men i 1903 oprettede nogle af byens lærlinge Skive Håndværkerlærlinges Boldklub »Olymphia«, som tilbød de samme aktiviteter som Skive Gymnastik- og Boldklub: kricket, fodbold og gymnastik. Først med sammenslutningen af de to klubber i 1908 fik Skive en stor og levedygtig idrætsklub, som kunne give et bredt tilbud til byens unge idrætsinteresserede mænd - og til kvinderne og drengene, der nu også kom med i klubben.

\section{Ud i den friske luft}

Hvorfor dyrke sport? Jo, de unge skulle ud i den friske luft efter de mange timer på 


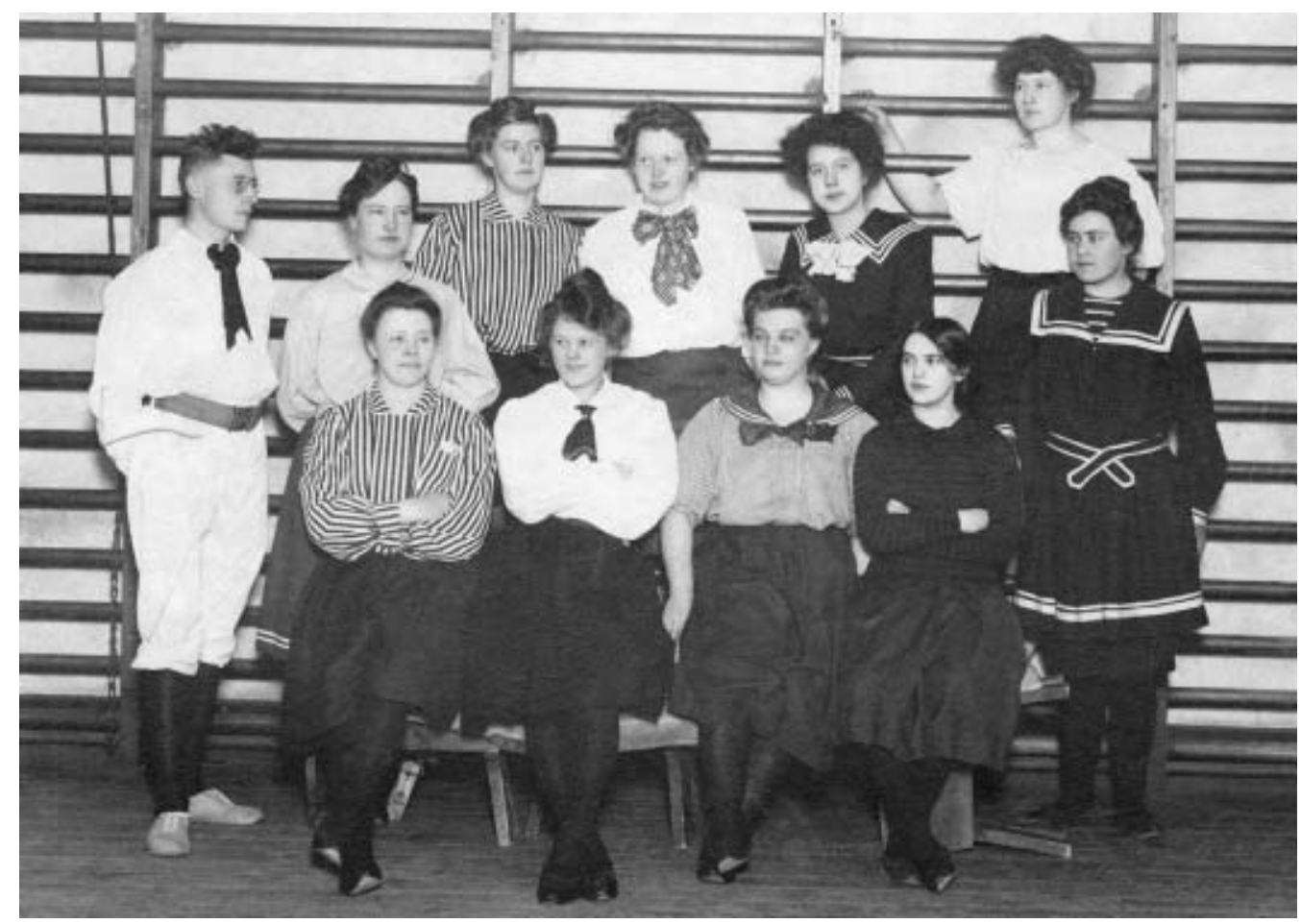

Efter 1900 begyndte kvinderne af komme med i idratsforeningerne. På landet blev der oprettet kvindegymnastikhold $i$ adskillige skytteforeninger, $i$ byen kunne kvinderne spille tennis, langbold eller håndbold. I 1908 oprettede Skive Idratsklub et gymnastikhold for kvinder. Kvinderne blev sikret to pladser $i$ klubbens bestyrelse, og som noget sarligt blev der indført ballotation ved optagelse af nye gymnaster på kvindeholdet. Her ses et af Skive Idratsklubs første kvindehold med klubbens gymnastiklarer Jens Hansen.

kontoret, værkstedet eller butikken, mente flere bekymrede læserbrevsskribenter i 1890'erne. Og hvad værre var, den fritid, de unge havde, brugte de på »at slå tiden ihjel i d $\phi s$ og dus«. Resultat: »Som det er nu, forsumper $d u$ aldeles. Du forkrøbles både på ånd og legeme, dit фje er slфvt og dit blik mat [...] Du mangler fuldstondig energi og legemskraft. Og som dit legeme, så din sjcel «. I I dette tilfælde var løsningen at melde sig ind i Skive Boldklub og spille kricket dér, men det kunne også være roning: »... Hvilken ganske anden sund og vaerdig idrat vil en søndag tilbragt med den udviklende roning ikke vare for de unge mennesker end den nu sadvanlige anvendelse ${ }^{8}{ }^{8}$

En skibonit levede i særlig grad op til idealet om at komme ud i naturen og hærde sig i den friske luft. Den 27. januar 1914 optrådte han i nøgen figur på forsiden af dagbladet Politiken. Under billedet stod der bl.a.:

$» V i$ bringer et billede, der vil forbavse

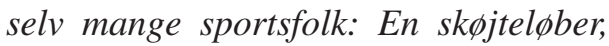
der foretrakker at lobe på skøjter uden noget som helst på ud over de sardeles 


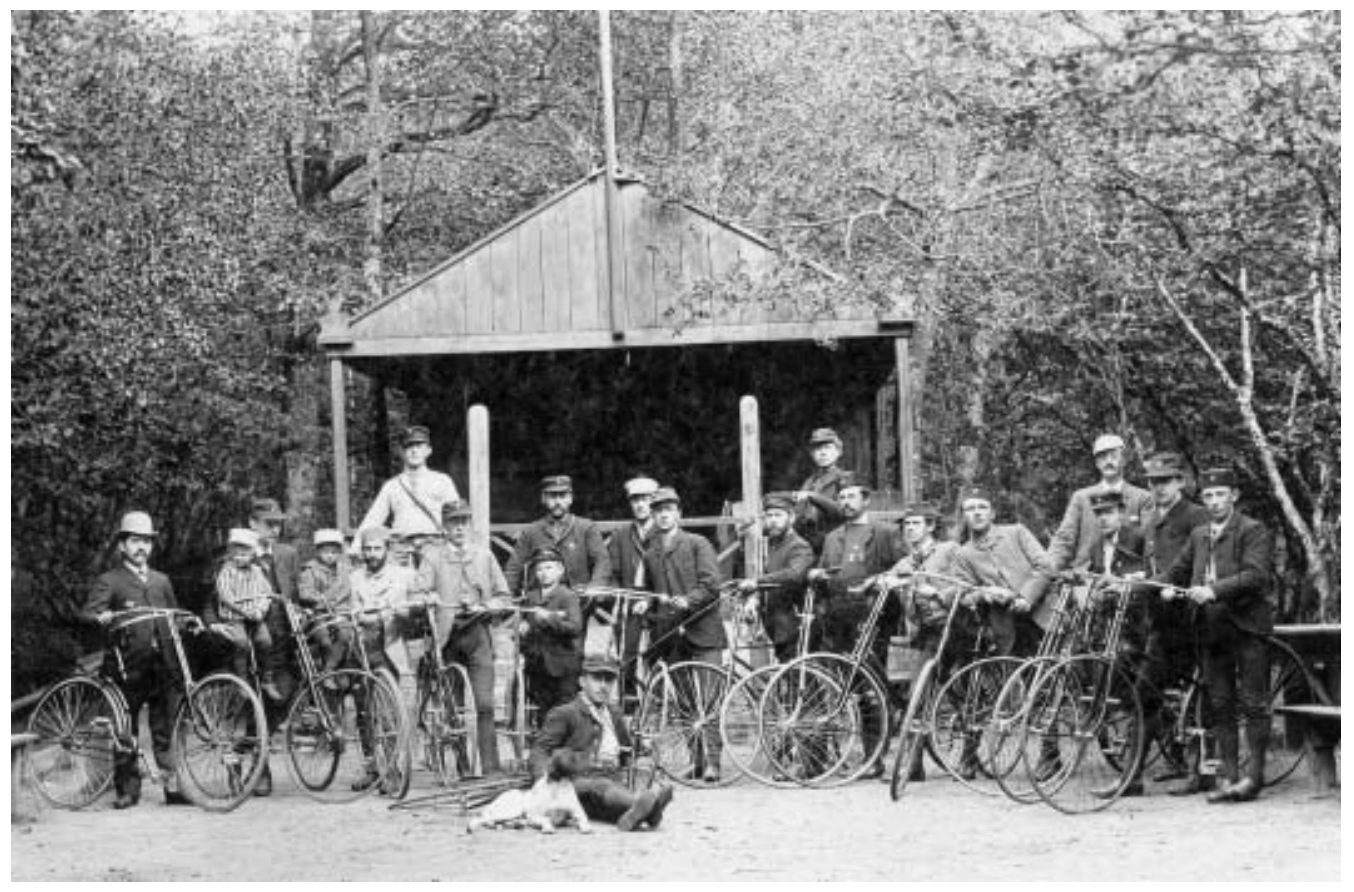

»Turistcykling « var den vigtigste aktivitet $i$ de forste cykelklubber, som nok arrangerede cykell $\phi b$, men lagde hovedvagten på ture til nabobyerne eller naturskфnne steder. Her holder medlemmer af Skive Cykleklub (1889-1893) i Skives gamle anlag »Liselund «klar til at køre en tur til anlaegget »Borgvold « $i$ Viborg. Klubbens formand, manufakturhandler Jean Sachs, står som nr. fem fra venstre i hvidt og med kalot. De to drenge i stribet tøj er Jean Sachs sønner, der fik lov til at komme med på turen.

nфdvendige støvler, til hvilke jernene skrues på. Han er J.P. Müllerianer om en hals, han er viking frem for nogen, denne raske unge mand, som ovenikøbet til daglig sidder $i$ et lummert banklokale $i$ en af vore provinsbyer og taller talkolonner sammen i store bøger $\ll$.

Den unge mand var bankassistent i den ellers yderst konservative Skive Bank, Carl Vilhelm Møller Hansen (1890-1973). Møller Hansen var inspireret af løjtnant J.P. Müllers gymnastiksystem. Ud over at løbe på skøjter i bar figur var han nøgen vinterbader i Skive Fjord og meget ivrig kælker.
Om sommeren dyrkede han lystfiskeri, fodsport og cykling. Som friluftsmenneske blev han interesseret i spejderbevægelsen. Fra 1910-1911 var han delingsfører i Frivilligt Drenge Forbund, hvorefter han meldte sig ud, formentlig i utilfredshed med korpsets religiøse præg. I 1914 stiftede han Det danske Spejderkorps 1. Skive Trop »Drenges Vel«, hvor han var tropsfører i en årrække.

Møller Hansens brug af nøgenkulturen vakte - selvfølgelig! - stor opsigt i det bornerte Skive, og det var med til at give ham et noget ufortjent ry som en af Skives originaler. 
Skives sportsklubber

Skive Skøjteløberforening 1885-1886

Skive Cykleklub 1889-1893

Skive Cykleklub/Dansk Cykle Rings

Skivekreds 1896-1905

Skive Boldklub 1896-1901

Ungdomslogen »Fremtidens Lykke «s

kricketklub »Skjold «1900-1903

Skive Roklub 1901-1911

Skive Gymnastik- og Boldklub/Skive

Idrætsklub 1901-

Skive Håndværkerlærlinges Boldklub

»Olymphia« 1903-1908

Skive Tennisklub 1905-1916

\section{Sportsklubberne i Skive}

Listen over Skives sportsklubber viser, at byens unge fra midten af 1890'erne havde en lang række muligheder for at dyrke sport. Ud over de sportsgrene, som fremgår af foreningernes navne, kunne de unge mænd også dyrke boksning, brydning og atletik, mens kvinderne kunne dyrke langbold og håndbold.

I kortere perioder - men ikke hele tiden. Som det fremgår af listen over sportsforeninger, fik de fleste foreninger et kort liv. Det skyldes ikke mindst, at foreningerne henvendte sig til en trods alt begrænset kreds af unge mænd, 100-150, nogle få kvinder og store drenge. Nøglegruppen, de unge mænd, var ret ustabile. Mange var i lære i Skive og rejste efter læretiden på valsen eller til en anden by, hvis de da ikke skulle springe soldat. Derfor blev det kun nogle få sportsfolk, der bar byens foreninger. »Løsningen « på problemet blev, at alle Skives sportsudøvere efterhånden samledes i Skive Idrætsklub, der til gengæld kunne tilbyde medlemmerne fodbold, atletik, boksning, tennis og gymnastik m.m.

\section{Sporten i byen og på landet}

Ovenfor er redegjort for, hvordan mange ledere i Skiveegnens skytteforeninger prøvede at forhindre, at skydningen og gymnastikken blev til sport og præmiejag. Det var en kamp, der var temmelig forgæves, for de unge på landet viste sig at være lige så interesserede $\mathrm{i}$ sporten som de unge $\mathrm{i}$ byen.

Det kommer klart til udtryk, når man ser nærmere på de to sportsgrene, der i årtierne omkring århundredskiftet 1900 fik flest udøvere: cykling og fodbold.

Egnens første cykelklub blev oprettet i Skive i 1889. Klubben havde en del medlemmer fra Salling, deriblandt klubbens bedste cykelryttere. Det tog syv år, før den første cykelklub blev oprettet på landet. I 1896-1897 blev der oprettet fire cykelklubber i Salling og Fjends - i stationsbyer eller stationsbylignende landsbyer. Medlemstallet for disse klubber kendes ikke, men der er ingen tvivl om, at cykelklubberne på landet tilsammen havde flere medlemmer end klubben i Skive. Landcykelklubberne eksisterede frem til århundredskiftet, hvor sportsinteressen i by og på land skiftede til fodbold.

Boldspillene dukkede op på samme tid $\mathrm{i}$ byen og på landet - i begyndelsen af 1890'erne. I Skive tilbød Skive Gymnastikforening i 1890-1891 medlemmerne at spille kricket og fodbold om sommeren, i Ørum-Tårup Skyttekreds i Nordfjends spillede skytterne kricket i sommeren 1891. I Skive var kricketspillet det dominerende boldspil i perioden 1896-1905, hvor det blev spillet i Skive Boldklub/Skive Gymnastik- og Boldklub, »Skjold « og »Olymphia«, mens der findes enkelte eksempler fra landet, alle umiddelbart efter århundredskiftet, hvor der f.eks. i 1902 blev spillet kricket i Rødding Skyttekreds 


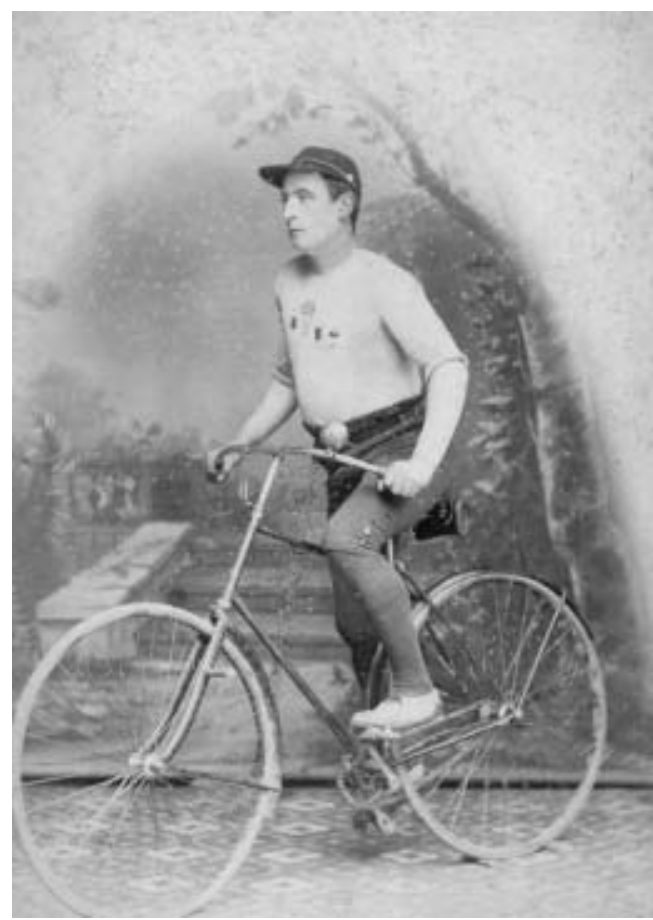

Mejeriejer, gymnastiklaerer og cykelhandler Esper Andersen, Jebjerg, med sin specialimporterede »Rudge cykel på $15 \mathrm{~kg}$, som han vandt Jylland Rundt på i 1892. På brystet hanger medaljer for vundne cykel$l \phi b$.

(Vestsalling) og i 1904 i Højslev BoldtForening (Nordfjends).

Det tredje engelske boldspil, tennis, dukker op i Skive i 1905 og 1907-1910 i et par af stationsbyerne ved Sallingbanen.

\section{»Salling-cykelrytterne»}

I august 1892 fandt en af 1890'ernes største lokale sportsbegivenheder sted. En sallingbo, medlem af Skive Cykleklub, opnåede europæisk berømmelse som cykelrytter!

Mejeriejer, cykelhandler og gymnastiklærer på Salling Højskole, Esper Andersen, vandt cykelløbet Jylland Rundt, det hidtil længste, der var kørt i Danmark. Det var på i alt 77 mil (ca. $550 \mathrm{~km}$ ), som skulle køres i et stræk. Løbet startede den 7. august 1892 i Århus. Ruten gik til Kolding, via Herning til Ringkøbing, derefter over Holstebro, Skive, Viborg og Hobro til Ålborg og via Randers til målet i Århus. Løbet samlede 18 deltagere, deriblandt nogle af datidens bedste danske cykelryttere. Esper Andersen gennemførte Jylland Rundt på 36 timer og ti minutter. Men ikke nok med det. Et andet medlem af Skive Cykleklub, Randrup fra Rybjerggård i Salling, blev nr. tre, og en student fra København, L. Andersen, der var født i Hindborg i Salling, blev nr. fire.

»Salling-cykelrytterne«s sejr vakte kolossal opsigt. Esper Andersen havde slået nogle af de bedste københavnske cykelryttere, og det fik københavneravisen Politiken til under overskriften $»$ Bondens sejr bl.a. at skrive:

»En sådan prastation viser, hvor uendeligt langt vore bonder er forud for andre landes $i$ kultur. I udlandet ville noget sådant vare utonkeligt og man ville føle disse jyske bønders ridt som et budskab fra det 20. århundrede $\ll .{ }^{9}$

Politikens vurdering kunne ikke være mere forkert. Esper Andersen var ingen »jysk bonde« - han var en topprofessionel sportsmand. Han havde som ung (f. $1859 \mathrm{i}$ Lyby i Salling) været medlem af JebjergLyby Skyttekreds. Han kom på den grundtvigianske Galtrup Højskole på Mors og senere på Ladelund Mejeriskole (v. Askov), hvor han uddannede sig til mejerist. I 1884 startede han et fællesmejeri i Jebjerg og blev samme år ansat som gymnastiklærer på den ligeledes nystartede Salling Højskole. I 1888 anskaffede han som den før- 


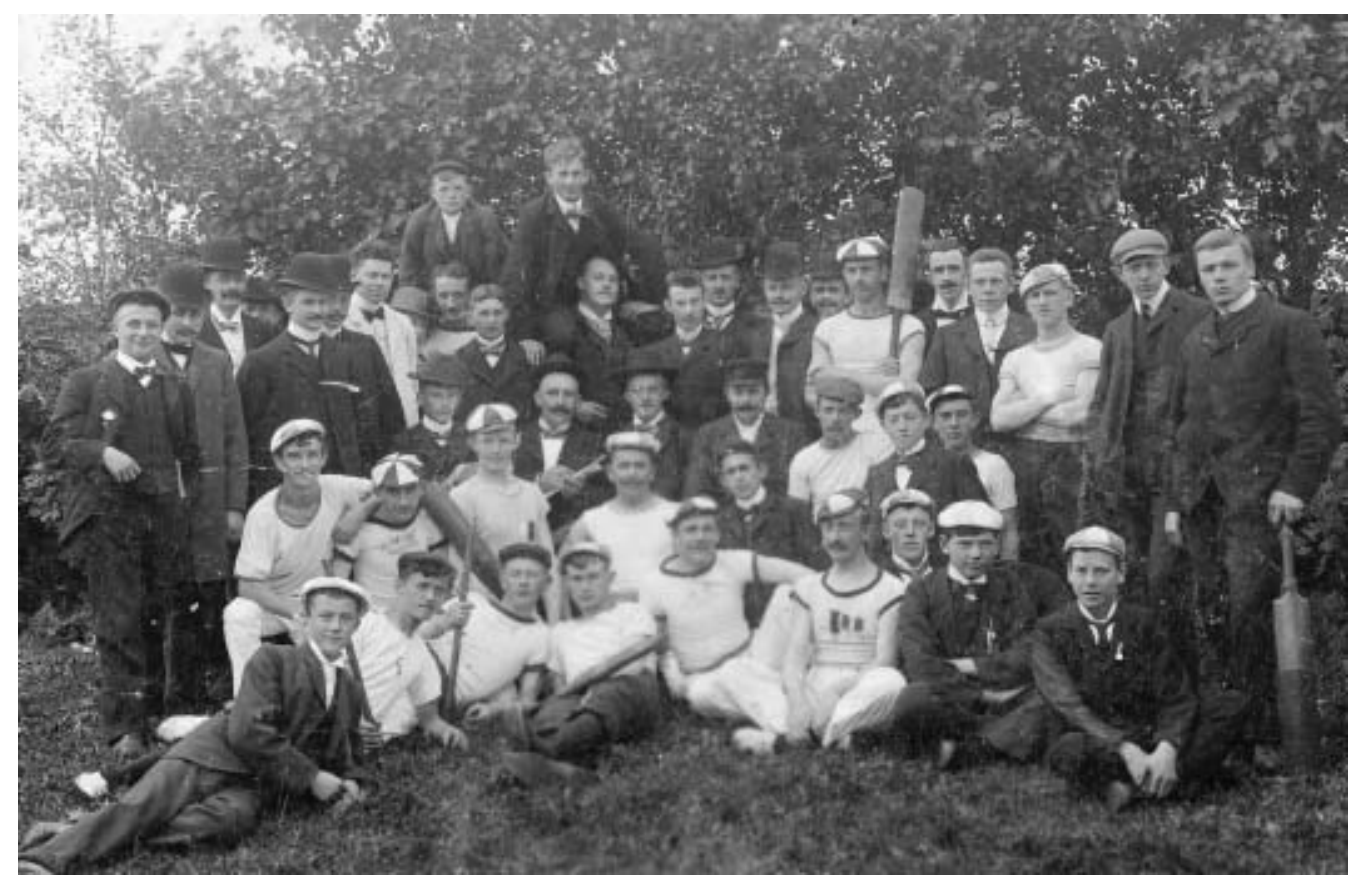

Skive Gymnastik- og Boldklubs krickethold til kamp hos naboklubben i Nykøbing Mors sommeren 1902. Skivespillerne kan kendes på de tofarvede kasketter. Kricketspillet фvede en vis tiltrakning iscer på de unge i Skive i tiåret 1896-1905, men blev så slået fuldstcendigt af banen af fodbolden.

ste i Salling en cykel, og to år senere åbnede han en cykelforretning, »Jyden«, ved mejeriet sammen med sin broder, Peder Andersen, der også var mejerist. Sammen med nogle af mejeristeleverne begyndte de to brødre i begyndelsen af 1890 'erne at køre cykelløb.

Esper Andersen greb cykelløbet Jylland Rundt professionelt an. Han anskaffede en specialbygget »Rudge«, der kun vejede 15 kg. Kosten under cykelløbet var også gennemtænkt. I Ålborg spiste han et råt æg, et par skiver franskbrød og drak en kop bouillon. I alt spiste han 25 rå æg, en kylling og tre bøffer under løbet! Det var tilladt at bruge pacere, og Esper Andersen brugte sin bror, Peder, og to andre brødre samt en af Sallings bedste cyklister, Dalsgaard.

Førstepræmien var på 200 kr., men Esper Andersen var formentlig lige så glad for den reklame, som han opnåede. Han var i fuld gang med at udbygge cykelforretningen i Jebjerg, og Peder Andersen havde startet en tilsvarende cykelforretning i Gedsted i Himmerland. I 1894/95 startede de to brødre cykelfabrikken $» \mathrm{Jy}$ den $\ll$ i Gedsted, der efter en brand i 1899 flyttedes til Ålestrup. Fabrikken nåede hurtigt op på en produktion på 12.000 cykler om året og en millionomsætning.

De to brødre, der i de følgende år vandt en lang række cykelløb, forstod at opdyrke det jomfruelige, men store cykelmarked. Opslag i brandforsikringsprotokoller fra 


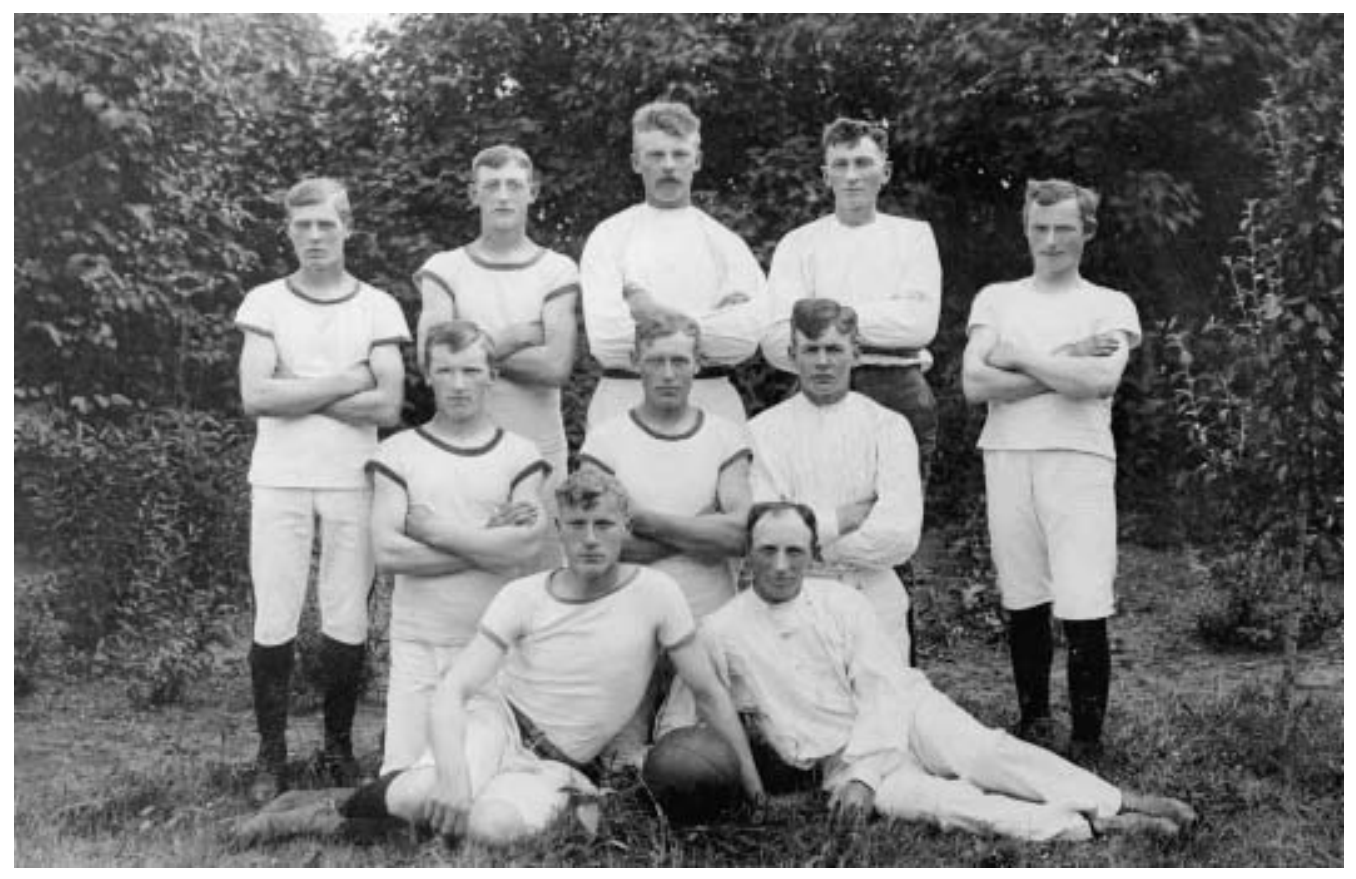

Rettrup Fodboldforenings førstehold i 1909. Fodboldforeningen var en af de første i Sydvestsalling. Blandt spillerne ses ungkarl Karsten Norgaard som nr. et fra venstre i midterste rakke. Bag på billedet har han noteret sin fodboldkarriere: Lihme 1906 (her var han født), Lihme førstehold 1907, Rettrup førstehold 1908-1909. Han sluttede fodboldkarrieren $i$ Lund-Vinde, hvor han havde købt en gård.

1890 'erne viser, at cyklen begyndte at blive almindelig blandt de unge karle og piger på landet. Ofte var cyklen det mest værdifulde, de ejede. Cykelklubben var en mulighed for at vise det nye vidunder frem og samles med ligesindede. I 1890'ernes cykelklubber lagde man hovedvægten på »turistcykelture «, mens cykelkonkurrencer var mere sjældne. Ud over Skive blev der i 1896-1897 oprettet cykelklubber i Jebjerg (Esper Andersen og mejeristerne), Balling og Durup i Salling samt Højslev i Nordfjends. Aktiviteterne i Højslev og Omegns Cykleklub er karakteristisk for disse klubber. Medlemmerne cyklede lange udflugtsture, og i klubbens fireårige liv arran- gerede klubben kun et cykelløb om præmier.

Ved århundredskiftet eller lige efter forsvandt næsten alle cykelklubberne. De sportsinteresserede unge kastede sig i stedet over boldspillene, især fodbold.

\section{Fodbold-det nye århundredes boldspil}

Blandt egnens første fodboldspillere finder vi meget passende cykelpioneren Esper Andersen, der var med til at introducere fodboldspillet i Jebjerg i 1900. Om det var på Salling Højskole, i skyttekredsen, gym- 
nastikforeningen eller i form af en ny fodboldforening, er ikke klart, men den gamle sportspioner var her med til at sparke en udvikling i gang, som i løbet af få år gjorde fodbold til en næsten lige så populær idrætsgren som skydning og gymnastik i Salling.

$\gg$ Fodboldforeningen $\ll$ blev den organisationsform, som man valgte de fleste steder, hvor man ønskede at gå i gang med det nye spil.

»Fodbold-Forening. De beboere $i$ Vejby og narmeste omegn, som фnsker at deltage $i$ en Fodbold-Forening bedes mode $i$ Vejby Forsamlingshus fredag den 19. juni, aften $k l .8 \ll .{ }^{10}$ En beskeden annonce i avisen var som regel nok. Kom der bare 11, var der et hold, og man kunne gå i gang.

Inspiration kunne hentes i Skive Folkeblad, hvor en indsender i 1901 skrev:

»Den er let at få igang, da den kun fordrer bold til $12 \mathrm{kr}$. samt nogle målstanger og markeflag. ... Fodbold er et fortraffeligt spil ... Det fremmer folelsen for kammeratskab i høj grad, udvikler hurtighed og snarrådighed og kraver desuden en vis grad af selvbeherskelse og hensynsfuldhed. Det vakker modet, styrker udholdenheden $« .{ }^{11}$

Indsenderen anbefalede fodbold til skyttekredsene som et godt supplement til skydningen om sommeren. Hvorvidt opfordringen blev fulgt, er svært at afgøre, da langt de fleste fodboldforeninger er anonyme ligesom annoncørerne fra Vejby - men der findes flere eksempler på, at skyttekredse har været indblandet i fodboldspil. I Højslev (Nordfjends) annonceredes oprettelsen af Højslev Boldt-Forening i 1904 i en artikel om Højslev Skyttekreds' gymnastikafslutning, og tre af medlemmerne i den nye forenings bestyrelse, bl.a. formanden, lærer Veggerby, deltog på skyttekred- sens gymnastikhold. I Rødding (Vestsalling) er Rødding Boldklub (stiftet 1905) formentlig en videreførelse af Rødding Skyttekreds' krickethold, i hvert fald spiller boldklubben på pladsen ved skyttekredsens skydebane. I Ejsing (Ginding Herred) slog man ligeledes i 1904 skytteforeningen og fodboldforeningen sammen under en bestyrelse.

På grund af fodboldforeningernes anonyme karakter og det manglende kildegrundlag - ingen af fodboldforeningerne i Salling og Fjends har efterladt sig et arkiv - er det vanskeligt at sige, hvem der stod bag oprettelsen af dem, men meget tyder på, at det de fleste steder var »ungdommen«. Om fodboldforeningen i Lihme (Vestsalling) hedder det i 1905: »I Lihme har ungdommen i foråret stiftet en fodboldforening, der allerede taller ca. 40 medlem-

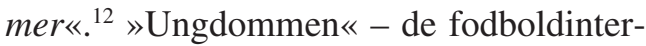
esserede unge mænd - gik selv i gang. De kunne let finde en mark, der var egnet til bane, målstænger og mærkeflag kunne de selv lave, og $12 \mathrm{kr}$. til en bold var til at overkomme.

Væksten i antallet af fodboldforeninger på Skiveegnen var nærmest eksplosiv:

Fodboldforeningernes stiftelsesår

1901: 2

1903: 2

1904: 7

1905: 7

1906: 2

1907: 3

1908: 1

1910: 3

I alt 27 fodboldforeninger blev der oprettet i det første årti af det 20. århundrede. Allerede i 1905 var der så mange foreninger, at det var muligt at organisere en turnering. Skive og Omegns samvirkende Fodbold- 
foreninger blev oprettet som paraplyorganisation for egnens fodboldforeninger, som næsten alle deltog i organisationens kampe og -turneringer, som hvert år afsluttedes med en sportsfest i Skive, hvor de afgørende kampe blev spillet. I 1910 faldt de fleste af klubberne fra. Det lykkedes ikke at få turneringen i gang, og Skive og Omegns samvirkende Fodboldforeninger gik i opløsning. Det standsede dog ikke fodboldspillet på Skiveegnen. Klubberne spillede mod naboklubberne - og der var altid bal bagefter - »bold-dans « blev det kaldt. I 1919 begyndte Skive Idrætsklub at arrangere en årlig landbopokalturnering. Efter den første turnering oprettede syv klubber i Nordsalling Nordsalling Boldunion - det første skridt til en fodboldturnering for klubberne i Salling og Fjends.

Selv for et så lille område som Skiveegnen var der stor forskel på, hvor mange, der spillede fodbold. Interessen var størst i det sydvestlige Salling, hvor der blev oprettet 12 fodboldforeninger $i$ årene 19031906. Derimod blev der kun oprettet fire foreninger i det $\varnothing v$ vrige Salling (1904-1910) og fem i Fjends (1904-1907). Hvorfor der er så stor forskel på fodboldinteressen, kan man kun gisne om, men en forklaring kunne være, at fodbold slog stærkest igennem de steder, hvor skyttebevægelsen stod svagest. I Sydvestsalling var der i 1904 kun ni skyttekredse, i det $\varnothing$ vrige Salling 13 og i Fjends hele 22. Men ti af Fjends Herreds skytteforeninger fandtes i de fire sogne, der havde en fodboldforening: Højslev (fire skyttekredse), Hald (to), Ørum (en), Søby (to) og Vridsted (en). Det er også påfaldende, at fodbold på landet først og fremmest blev spillet i de »rene « landsogne, mens f.eks. stationsbyerne langs Sallingbanen var mere langsomme til at tage spillet op. Derimod var tennis et »stationsby-spil.«
I købstaden Skive var der kamp om boldspillerne. Fra 1900-1903 spillede byens tre boldklubber, Skive Gymnastik- og Boldklub, ungdomsafholdslogens boldklub »Skjold « og håndværkerlærlingenes boldklub »Olymphia« alle kricket. I 1904 var »Skjold« gået i opløsning, mens »Olymphia« skiftede over til fodbold. Skive Gymnastik- og Boldklub holdt fast ved kricket indtil foråret 1905, hvor fodbold totalt fortrængte kricketspillet.

På dette tidspunkt var de to boldklubber lige store, men »kampen « mellem dem endte med en sammenlægning i 1908, hvor »Olymphia blev kollektivt indmeldt i Skive Idrætsklub (SIK), som Skive Gymnastik- og Boldklub (SGB) hed siden 1906. »Olymphia « havde tilknytning til Skives arbejderbevægelse, mens SGB/SIK mere var borgerskabets klub. »Olymphia« spillede med i Skive og Omegns samvirkende Fodboldforeningers (SOsF) turneringer og kunne derudover tilbyde spillerne kampe mod andre »Olymphia«-klubber, f.eks. i Nykøbing Mors, Viborg og Århus. SGB deltog også i SOsF's turneringer, men indmeldte sig i 1905 i Jydsk Boldspil Union (og senere Dansk Boldspil Union). Det betød, at klubbens spillere fik mulighed for at spille mod store klubber i andre jyske købstæder - sikkert en trumf i kampen mod »Olymphia«.

\section{Skytte, gymnast, cyklist og fodboldspiller}

I 1906 var der 351 skytter og 348 gymnaster i foreningerne under Salling Herreders Skytteforening (Salling, Skive og den nordøstlige del af Ginding Herred). I samme år fandtes der ca. 15 aktive fodboldforeninger på landet (hvoraf flere havde A- og B-hold) og to i Skive i samme område. 
Land-fodboldforeningerne havde mindst 200 medlemmer - formentlig langt flere, hvis man tager udgangspunkt i tallet fra Lihme i 1905: 40 medlemmer - hvortil kom ca. 80 i Skive. Under alle omstændigheder kunne fodbold matche de traditionelle idrætsgrene skydning og gymnastik såvel på landet som i byen.

Lægger man tallene sammen, var antallet af idrætsudøvere i Salling i 1906 på omkring 1.000, men det reelle tal har været lavere. Også for 100 år siden »shoppede « idrætsudøverne rundt mellem klubberne uden at spekulere på, om man deltog $\mathrm{i}$ skyttebevægelsen eller i en sportsklub under Dansk Idrætsforbund. Man kunne sagtens være med begge steder.

Mejeriejer og cykelhandler Esper Andersen, Jebjerg, er et eksempel. Han startede i skytteforeningen, fortsatte med gymnastik (som højskolelærer og i skytteforeningen), samtidig med at han var halvprofessionel cykelrytter - og endte med at spille fodbold. Et andet eksempel kan være lærer A. Jacobsen, Skive, der var lønnet gymnastikleder i Skive Gymnastik- og Boldklub (medlem af JBU og DBU), samtidig med at han som medlem af Skive Skyttekreds deltog i Salling Herreders Skytteforenings generalforsamlinger, hvor han ofte tog ordet. Et tredje eksempel kan være den unge tømrersvend Jeppe Jeppesen, Højslev, der i 1899 sad i bestyrelsen for Højslev og Omegns Cykleklub, samtidig med at han som medlem af Højslev Skyttekreds vandt præmie i en kapskydning - og i 1904 blev bestyrelsesmedlem i Højslev Boldt-Forening sammen med tre gymnaster fra Højslev Skyttekreds.

Bare der var bal bagefter - og det var der: skyttebal, gymnastikbal, fodbolddans - og der var mulighed for at komme sammen med andre unge med samme interesse på en udfordrende og spændende måde der skulle helst være konkurrence og præmier! - så var de fleste idrætsudøvere nok temmelig ligeglade med den ideologiske overbygning, som bekymrede præster, lærere og andre ungdomsopdragere lagde ned over idrætten?

\title{
Noter
}

1. Skive Folkeblad, 9/7 1888.

2. Ibid., 5/5 1915.

3. Ibid., 9/7 1896.

4. Ibid., 1/9 1903.

5. Ibid., 18/5 1901.

6. Ibid., 13/4 1896.

\author{
7. Ibid., 13/4 1896. \\ 8. Ibid., 28/2 1899. \\ 9. Citeret i Skive Avis, 15/8 1892. \\ 10. Skive Folkeblad, 19/6 1903. \\ 11. Ibid., 18/5 1901. \\ 12. Ibid., 28/5 1905.
}

\section{Litteratur}

Oversigt over kilder og litteratur om Skiveegnens tidlige idratshistorie kan findes i:

Niels Mortensen, »En sund sjæl i et sundt legeme. Idræt på landet 1861-1914«. I: Skivebogen (1987), s. 84-115 og (1987), s. 37-61.

Niels Mortensen, »Kilometer-Hansen: Skibonit på skøjter uden tøj i 1914«. I: Skiveegnens Jul (1993), s. 5-9.
Niels Mortensen, »Da sporten kom til Skive. Skives idrætshistorie indtil 1914«. I: Skivebogen (1997), s. 110-162.

Niels Mortensen, 1901-1949. SIK Skives idratsklub gennem 100 år (2000). 